\title{
KONSEP MUSAQAH DALAM FIKIH DAN RELEVANSINYA DENGAN KERJASAMA 'MARO' ANTARPETANI KOPI (STUDI DI DESA GUNUNG SARI, ULU BELU, TANGGAMUS)
}

\author{
Ledy Famulia \\ Universitas Sang Bumi Ruwa Jurai \\ ledyfamulia95@gmail.com
}

\begin{abstract}
Abstrak
Konsekuensi logis dari ditetapkannya Indonesia menjadi negara agraris adalah bahwa sektor pertanian memiliki peranan penting dalam memajukan perekonomian nasional. Umumnya, sektor pertanian ini dibagi menjadi dua bagian, yaitu perkebunan besar dan produksi petani kecil. Apabila melihat fakta yang terjadi, kehidupan para petani perlu mendapat perhatian lebih karena masih jauh dari kata sejahtera. Salah satu bentuk kerjasama yang sering dilakukan para petani disebut dengan 'maro'. Misalnya adalah yang terjadi di Desa Gunung Sari, yaitu kerjasama pengelolaan kebun kopi. Islam sebagai agama mayoritas penduduk, memiliki konsep tersendiri mengenai kerjasama antarpetani dalam pengelolaan lahannya, yakni ada yang disebut muzara'ah, mukhabarah dan musaqah.. Penelitian ini menggunakan metode kualitatif, dengan jenis penelitian berupa deskriptif analitis. Pendekatan Penelitian yang digunakan adalah case approach atau pendekatan kasus, sedangkan teknik analisis data yang didasarkan pada metode interpretasi teleologis. Hasil penelitian menunjukkan bahwa tidak ada konsep baku mengenai kerjasama 'maro' antarpetani kopi di Desa Gunung Sari. Meski demikian, secara garis besar konsep kerjasama ini sejalan dengan konsep musaqah yang ada dalam Fikih Islam. oleh sebab itu, di harapkan kedepan terdapat aturan baku mengenai konsep kerjasama musaqah ini, sehingga para petani kopi yang mayoritas beragama Islam dapat mempraktikkan kerjasama yang sejalan dengan syariat Islam.
\end{abstract}

Kata Kunci: kerjasama, musaqah, maro

\begin{abstract}
Logical consequence of the establishment of indonesia as the agraris is that the agricultural sector has an important role in advancing the national economy. Generally, the agricultural sector is divided into two parts, that is a large estate and the production of small farmers. If they find a fact that occurs, the farmers need to receive more attention as it was far from a prosperous. One form of cooperation often held by farmers called 'maro'. For example that occurred in the Gunung Sari, namely cooperation to manage a coffee. The majority of the population of Islam as a religion, have the concept of a separate antarpetani about cooperation in the management of their land, is called muzara'ah, mukhabarah and musaqah.This research uses qualitative methods, with the type of research in the form of descriptive analytical. The research approach used is the case approach, while the data analysis technique is based on teleological interpretation methods. The results show that there is no standard concept of 'maro' cooperation between coffee farmers in Gunung Sari Village. However, in general, the concept of cooperation is in line with the concept of musaqah in Islamic Fiqh. Therefore, it is hoped that in the future there will be standard rules on the concept of musaqah cooperation, so that coffee farmers, the majority of whom are Muslims, can practice cooperation in line with Islamic law.
\end{abstract}

Keywords: cooperation, musaqah, maro

\section{PENDAHULUAN}

Berdasarkan Laporan Badan Pusat Statistik, Lampung merupakan provinsi kedua dengan luas tanaman perkebunan kopi setelah Sumatera Selatan, yaitu mencapai 154.80 ribu hektar per tahun 2018. Hal ini membuktikan bahwa perkebunan kopi merupakan salah satu mata pencaharian penduduk yang utama, terutama bagi mereka yang tinggal di daerah pegunungan, salah satunya di Kecamatan Ulu Belu, Tanggamus. Mayoritas penduduk yang tinggal di daerah tersebut merupakan petani kopi. Meski harga kopi terbilang stabil, namun tidak semua petani kopi yang berada di Ulu Belu tergolong masyarakat menengah. Banyak dari mereka yang bekerja pada petani lain yang memiliki kebun kopi lebih luas. Selain itu ada pula sebagian dari mereka yang bekerja dengan cara bermitra dengan petani yang memiliki kebun kopi lebih luas 
untuk mengelola perkebunan kopi tersebut dengan konsep bagi hasil. Dalam bahasa mereka, kerjasama bagi hasil ini disebut dengan 'maro'.

Dalam Islam, yang merupakan agama mayoritas penduduk Indonesia khususnya di Lampung, dikenal pula berbagai konsep kerjasama untuk pengelolaan sebuah lahan pertanian, yang disebut dengan muzara'ah, mukhabarah dan musaqah. Muzara'ah adalah kesepakatan dan kebersamaan dalam mengelola lahan pertanian antara pemilik dan penggarap dengan ketentuan bahwa benih bersumber dari pemilik lahan. Adapun mukhabarah diartikan sebagai pengerjaan lahan yang selanjutnya diikuti dengan pembagian hasil panen, dengan ketentuan bahwa benih berasal dari penggarap. Sedangkan musaqah yakni kerjasama yang dilakukan oleh dua pihak atau lebih dimana pemilik kebun memberikan kebunnya kepada tukang kebun agar dipelihara dan penghasilan yang didapat dari kebun itu dibagi antara keduanya sesuai kesepakatan. (Arif, 2018) Apabila melihat ketiga konsep tersebut, konsep kerjasama 'maro' antarpetani kopi yang dilakukan di Desa Gunung Sari lebih condong pada ketentuan yang terahir, yaitu musaqah, karena pada saat pengelolaan, kebun kopi sudah siap dikelola dengan tanpa diawali dengan penanaman benih terlebih dahulu. Secara lebih jauh, kerjasama dalam Islam dalam bentuk musaqah ini menarik dan urgen untuk diteliti, guna melihat sejauh mana relevansinya dengan kosep kerjasama 'maro' antarpetani kopi yang ada di Desa Gunung Sari, tersebut. Dalam kaitannya dengan pemilihan desa, dikarenakan desa ini merupakan pusat jual beli kopi di Kecamatan Ulu Belu, Tanggamus, Lampung. Rumusan masalah yang digunakan dalam penelitian ini adalah bagaimanakah konsep kerjasama 'maro' yang dilakukan para petani kopi di Desa Gunung Sari?, apakah makna otentik dari konsep musaqah dalam Fikih? Dan bagaimanakah relevansi konsep musaqah dalam fikih dan kerjasama 'maro' antarpetani kopi di Desa Gunung Sari?

Beberapa penelitian terdahulu yang mendukung penelitian ini diantaranya: pertama, penelitian yang dilakukan oleh Wahyuningsih (2011) tentang sistem bagi hasil 'maro' sebagai upaya mewujudkan solidaritas di masyarakat. Kesimpulan dari penelitian menunjukkan bahwa pelaksanaan perjanjian dapat meningkatkan perekonomian sekaligus memupuk solidaritas masyarakat (Wahyuningsih, 2018). Kedua, penelitian yang dilakukan oleh Imram dan kawankawan (2017), mengenai tinjauan hukum Islam mengenai akad musaqah terhadap praktek bagi hasil pertanian di Desa Karangheleut, Situraja, Sumedang. Kesimpulan dari penelitian ini adalah bahwa akad musaqah yang dilakukan di Desa Karangheleut ini tidak sah secara hukum Islam karena dalam akad tersebut masih mengandung riba. Hal ini terlihat dari isi perjanjian dimana pemilik lahan/ sawah menentukan bagian di awal akad, bukan dalam bentuk presentase (Imran, 2017). Ketiga, penelitian yang dilakukan oleh Ali (2019) mengenai pelaksanaan akad musaqah dalam pengelolaan lahan pohon kelapa di Desa Hutan Wana Tani Manunggal Karangbendo, Ponggok, Blitar. Kesimpulan penelitian menunjukkan bahwa pelaksanaan akad musaqah dalam pengelolaan lahan pohon kelapa telah memenuhi rukun dan syarat akad musaqah. Presentase bagi hasil sebesar 25\%:75\%. Akad musaqah antara Perum Perhutani dan Penggarap mampu meningkatkan perekonomian dan menciptakan kesempatan kerja bagi masyarakat setempat (Aziz, 2018).

Berdasarkan beberapa penelitian yang pernah dilakukan sebagaimana disebutkan di atas, penulis menyimpulkan bahwa penelitian yang akan dikaji berbeda dengan penelitian sebelumnya. Penelitian ini dilakukan dengan menggunakan metode kualitatif dengan interpretasi gramatikal dan teleologis, sedangkan kelima penelitian sebelumnya hanya sebatas mengukur terpenuhinya rukun dan syarat akad musaqah saja. Selanjutnya, mengenai teori-teori yang relevan sebagai dasar pentingnya dilakukan penelitian ini adalah sebagai berikut: Pertama, konsep bagi hasil dalam Islam. Bagi hasil sering disebut juga dengan profit sharing atau bagi untung, yakni bagi hasil yang dihitung dari pendapatan setelah dikurangi modal dan biaya yang telah digunakan. Dalam praktiknya, terdapat beberapa jenis akad yang 
menggunakan konsep bagi hasil, terutama akad-akad yang ada pada lembaga keuangan syariah seperti mudharabah dan musyarakah. Selain itu akad bagi hasil ini juga secara khusus ada yang diperuntukkan bagi kerjasama dalam bidang pertanian, yang disebut dengan muzara'ah, mukhabarah dan musaqah.Muzara'ah secara bahasa berarti kerjasama di bidang pertanian antara pemilik dan petani penggarap dengan ketentuan bahwa benih (bibit) tanaman berasal dari pemilik tanah. Sedangkan mukhabarah adalah bentuk kerjasama antara pemilik sawah/ tanah dan petani penggarap dengan perjanjian bahq hasilnya akan dibagi menurut kesepakatan bersama dan benihnya berasal dari petani penggarap (Ghazali, 2010)

Kedua, kerjasama Musaqah. Musaqah yaitu bentuk kerjasama di mana petani penggarap hanya bertanggungjawab dalam pengelolaan dengan imbalan dari hasil panen sesuai kesepakatan kedua belah pihak. Dasar hukum musaqah adalah hadis berikut:

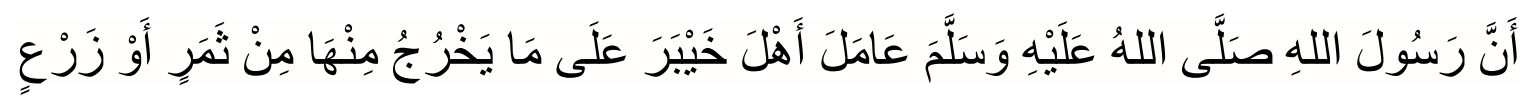

Artinya: "Bahwa Rasulullah SAW menyuruh penduduk khaibar untuk menggarap lahan di khaibar dengan imbalan separuh dari tanaman atau buah-buahan hasil garapan lahan tersebut.” (H.R. Muttafaq 'alaih)

Dari penjelasan hadis tersebut, para ahli fikih sepakat bahwa hukum akad musaqah adalah boleh. Rukun dan syarat musaqah menurut jumhur ulama adalah sebagai berikut:

1. 'Aqidain: dua pihak yang berakad, yaitu pemilik kebun dan petani penggarap. Syaratnya adalah cakap bertindak hukum, berakal, dan baligh.

2. Objek akad musaqah yakni berupa tanah dengan pepohonan di dalamnya.

3. Jenis usaha yang akan dilakukan petani penggarap.

4. Ketentuan bagi hasil musaqah.

5. Sighat: yaitu ungkapan ijab qabul

Ketiga, teori hermeneutika hukum. Secara etimologis, kata hermeneutik atau hermeneutika merupakan padanan kata dari bahasa Inggris hermeneutic dan hermeneutics. Hermeneutic merupakan bentuk adjective, apabila diterjemahkan artinya ketafsiran, yakni merujuk pada suatu keadaan atau sifat yang terdapat dalam satu penafsiran. Sedangkan hermeneutics merupakan bentuk noun, yang mengandung tiga arti, yaitu; ilmu penafsiran, ilmu untuk mengetahui maksud yang terkandung dalam kata-kata dan ungkapan penulis, dan penafsiran yang secara khusus merujuk pada penafsiran teks atau kitab suci (Hamidi, 2005) Hermeneutika mengajarkan bahwa pemahaman mengisyaratkan konteks makna yang berlaku pada masanya. Kajian hermeneutika hukum dimaksudkan tidak hanya membebaskan kajiankajian hukum dari otoritarianisme para yuris positif yang elitis, tetapi juga dari kajian hukum kaum strukturalis atau behavioralitas yang selalu empirik sifatnya. Secara umum metode penafsiran teks hukum dapat dikelompokkan ke dalam 11 macam, diantaranya interpretasi gramatikal, interpretasi historis, insterpretasi sistematis, interpretasi teleologis, interpretasi komparatif, interpretasi futuristik, interpretasi restriktif, interpretasi ekstensif, interpretasi otentik, interpretasi interdisipliner, dan interpretasi multidisipliner.

\section{METODE PENELITIAN}

Metode yang digunakan dalam penelitian ini adalah metode penelitian kualitatif, dengan jenis penelitian berupa deskriptif analitis. Pendekatan penelitian yang digunakan dalam penelitian ini adalah case approach atau pendekatan kasus, yaitu melihat fakta yang terjadi di masyarakat khususnya di Desa Gunung Sari mengenai kerjasama 'maro' antarpetani kopi. Penelitian ini bersifat evaluatif, yaitu penilaian terhadap suatu masalah hukum tertentu (reconstruction). Teknik pengumpulan data dilakukan dengan studi pustaka dan studi lapangan 
Seminar Nasional Penelitian dan Pengabdian kepada Masyarakat Universitas Sang Bumi Ruwa Jurai Tahun 2020

dengan bahan hukum primer berupa fakta di lapangan sekaligus aturan-aturan hukum terkait konsep kerjasama musaqah dalam Fikih serta bahan hukum sekunder dan tertier berupa sumber data penelitian yang diperoleh secara tidak langsung yaitu melalui media perantara. Selanjutnya analisis data yang didasarkan pada metode interpretasi teleologis, yaitu makna suatu hukum yang ditetapkan berdasarkan tujuan kemasyarakatannya.

\section{HASIL DAN PEMBAHASAN}

\section{Hasil Penelitian}

Penelitian dilakukan dengan cara observasi di Desa Gunung Sari, Kecamatan Ulu Belu, Kabupaten Tanggamus Lampung. Lebih lanjut dilakukan wawancara kepada beberapa narasumber yang terdiri dari dua kategori, yaitu petani yang pemilik kebun kopi, dan petani penggarap yang melakukan kerjasama 'maro' di Desa Gunung Sari. Petani pemilik kebun kopi diantaranya bapak Sugeng Riyanto, bapak Edi Irawan, dan bapak Sutoyo. Sedangkan petani kopi penggarap diantaranya bapak Sugeng Riyanto, bapak Agus dan bapak Surip.

Berdasarkan hasil wawancara yang dilakukan dengan beberapa narasumber selaku petani pemilik kebun kopi didapatkan fakta bahwa penyebutan maro biasanya diberikan kepada orang yang akan menggarap kebun, dalam hal ini yang menggarap kebun pak Sugeng bernama bapak Parmin. Dalam kerjasama maro tersebut, semua pengurusan kebun kopi mulai dari pemupukan, penyemprotan rumput dan semut, merapihkan batang pohon atau biasanya disebut dengan istilah ngeranting, memetik bahkan sampai menjemur dan menggiling kopi merupakan kewajiban dari petani penggarap. Namun, dalam rangka pemupukan, pembelian pupuk ditanggung bersama kedua belah pihak, hanya saja yang melakukan pemupukan menjadi kewajian petani penggarap. Pembagian keuntungan dilakukan setelah panen semua hasil kopi kemudian dijual dan hasilnya dibagi menjadi dua dengan presentase 50\%:50\%. Sedangkan hasil wawancara yang dilakukan kepada petani penggarap kebun kopi didapatkan fakta serupa, bahwa berbagai kewajiban petani penggarap berupa pemupukan, penyemprotan rumput dan semut, ngeranting, memetik bahkan sampai menjemur dan menggiling kopi.

Dalam memenuhi kewajibannya tersebut, terkadang penggarap mempekerjakan orang lain untuk membantu dalam hal pemetikan biji kopi. Semua biaya pekerja menjadi tanggungan bapak Sugeng selaku penggarap kebun. Dalam kaitannya dengan pembagian keuntungan, dibagi secara merata dengan presentase 50\%:50\%.

\section{Pembahasan}

\section{Konsep Kerjasama ‘Maro’ antarpetani Kopi di Desa Gunung Sari}

Istilah 'maro' yang digunakan untuk mengistilahkan kerjasama dengan membagi hasil panen antarpetani kopi di Desa Gunung Sari diambil dari Bahasa Jawa 'separo' yang artinya setengah, maksudnya adalah setengah hasil milik petani penggarap dan setengah hasilnya lagi untuk petani pemilik kebun.

Berdasarkan hasil wawancara yang telah dilakukan dari beberapa narasumber, kerjasama 'maro' antarpetani kopi pada umumnya dengan ketentuan presentase pembagian hasil sebesar 50\%:50\%. Mengenai pupuk maupun obat rumput dan obat serangga juga dibebankan kepada kedua belah pihak. Namun dalam pengerjaan kebun kopi secara keseluruhan menjadi kewajiban petani penggarap, yaitu berupa pemupukan kebun kopi, penyemprotan rumput dan serangga, merapihkan batang pohon (ngeranting), memetik buah kopi, menjemur kopi, menggiling kopi, bahkan ada yang sampai menjual kopi. Sehingga petani pemilik langsung mendapat bagian berupa uang hasil jual kopi yang telah dibagi antara kedua belah pihak. 


\section{Makna Otentik Konsep Musaqah dalam Fikih}

Secara bahasa musaqah berasal dari kata as-saqa. Kata ini digunakan karena dahulu pepohonan penduduk Hijaz membutuhkan penyiraman atau saqi dari sumur. Musaqah merupakan wazn mufa'alah dari kata as-saqyu yang bersinonim dengan kata asy-syurbu, artinya memberi minum. Sedangkan secara istilah menurut Abdurrahman al-Jaziri bahwa musaqah adalah akad untuk pemeliharaan pohon kurma, tanaman (pertanian) dan yang lainnya dengan syarat-syarat tertentu. Musaqah berarti penyerahan pohon kepada orang yang akan mengairi dan merawatnya sampai buahnya benar-benar matang dengan imbalan bagian tertentu dari buah tersebut. ${ }^{1}$

Dasar hukum musaqah adalah sebuah Hadis yang diriwayatkan oleh Muslim dari Ibnu Umar yang artinya adalah "sesungguhnya Rasulullah SAW telah memberikan kebun beliau kepada penduduk Khaibar agar dipelihara oleh mereka dengan perjanjian mereka akan memperoleh setengah dari penghasilannya, baik dari buah-buahan maupun tanamannya." Atas dasar hadis tersebut, jumhur ulama sepakat untuk memperbolehkan akad musaqah. Namun para ulama berbeda pendapat mengenai ketentuan musaqah. Menurut Abu Daud, yang boleh menjadi obyek musaqah hanya kurma. Sedangkan menurut Imam syafi'i, yang boleh musaqah hanya kurma dan anggur. Menurut Imam Hanafi, semua pohon yang mempunyai akar ke dasar bumi boleh dimusaqahkan. Imam Maliki dan Hambali menyatakan bahwa diperbolehkan semua pohon yang memiliki akar yang kuat dan berbuah, seperti kurma, tin, zaitun, dan sebagainya. Dengan demikian, maka secara umum, musaqah tidak hanya terbatas pada perkebunan kopi saja, tetapi juga pada objek yang lain yang memenuhi syarat sesuai ketentuan musaqah tersebut.

Dalam kaitannya dengan rukun dan syarat musaqah, jumhur ulama berpendapat bahwa rukun musaqah ada tiga, yaitu kedua pihak yang berakad (pemilik dan penggarap), objek akad berupa pekerjaan dan buah, serta ungkapan (sighat) akad. Adapun syarat musaqah yakni bagi kedua belah pihak harus berakal dan mumayyiz, objek akad harus pohon yang berbuah, membebaskan pemilik kebun atas pohon, dan kepemilikan bersama dalam hasil yang diperoleh. Apabila rukun dan syarat ini tidak terpenuhi maka dapat menyebabkan akad musaqah menjadi fasid (rusak).

Hikmah dari adanya akad musaqah adalah pertama, menghilangkan kemiskinan, karena orang yang memiliki kebun menyerahkan seluruhnya kepengurusan kebun kepada orang lain yang tidak memiliki kebun, dengan pembagian atas hasil yang didapat setelah panen. Kedua, saling tukar manfaat diantara manusia, dimana pemilik kebun memanfaatkan tenaga penggarap dan penggarap memanfaatkan lahan kebun petani pemilik, sehingga terjadi hubungan yang saling menguntungkan diantara keduanya. Dengan demikian, maka akan menimbulkan rasa saling peduli antarmanusia yang berujung oada mashlahah untuk keduanya.

\section{Relevansi Konsep Musaqah dalam Fikih dan Kerjasama 'Maro' antarpetani Kopi di Desa Gunung Sari}

Menurut Kamus Besar Bahasa Indonesia, relevansi adalah hubungan, keterkaitan, kesesuaian. ${ }^{2}$ Relevansi dimaknai sebagai suatu yang memiliki kebermaknaan terhadap suatu

${ }^{1}$ Ely Herawati, "Tinjauan Hukum Islam terhadap Musaqah antara Pemilik Kebun Karet dan Penyadap di Desa Tanjung Bulan Kecamatan Rambang Kuang Kabupaten Ogan Ilir”, Skripsi, UIN Raden Fatah Palembang, 2017. Hlm. 42.

${ }^{2}$ https://kbbi.kemdikbud.go.id/entri/relevansi diakses pada 9 September 2020. 
Seminar Nasional Penelitian dan Pengabdian kepada Masyarakat

Universitas Sang Bumi Ruwa Jurai Tahun 2020

konsep tertentu. Dalam konteks ini akan dibahas mengenai kebermaknaan konsep musaqah dengan kerjasama 'maro' antarpetani kopi di Desa Gunung Sari.

Praktik kerjasama 'maro' antarpetani kopi yang terjadi di Desa Gunung Sari merupakan salah satu bentuk kerjasama dimana petani pemilik kebun menyerahkan kepengurusan dan perawatan kebunnya kepada petani penggarap dengan bagi hasil diakhir masa panen yang disepakati kedua belah pihak. Selain pembagian hasil panen, pembelian bahan dalam rangka perawatan kebun berupa pupuk dan pestisida juga menjadi kewajiban yang ditanggung kedua belah pihak. Berkaitan dengan hal tersebut, Islam sebagai agama yang kaffah memiliki aturan tersendiri dalam pengelolaan kebun yang diklasifikasikan menjadi tiga, yaitu muzara'ah, mukhabarah dan musaqah.

Muzara'ah adalah kesepakatan dan kebersamaan dalam mengelola lahan pertanian antara pemilik dan penggarap dengan ketentuan bahwa benih bersumber dari pemilik lahan. Adapun mukhabarah diartikan sebagai pengerjaan lahan yang selanjutnya diikuti dengan pembagian hasil panen, dengan ketentuan bahwa benih berasal dari penggarap. Sedangkan musaqah yakni kerjasama yang dilakukan oleh dua pihak atau lebih dimana pemilik kebun memberikan kebunnya kepada tukang kebun agar dipelihara dan penghasilan yang didapat dari kebun itu dibagi antara keduanya sesuai kesepakatan. ${ }^{3}$ Apabila melihat ketiga konsep tersebut, konsep kerjasama 'maro' antarpetani kopi yang dilakukan di Desa Gunung Sari lebih condong pada ketentuan yang terahir, yaitu musaqah, karena pada saat pengelolaan, kebun kopi sudah siap dikelola dengan tanpa diawali dengan penanaman benih terlebih dahulu.

Konsep musaqah yang dikenal dalam Fikih apabila ditinjau menggunakan interpretasi gramatikal berasal dari kata as-saqa yang berarti penyiraman. Menurut Abdurrahman al-Jaziri musaqah adalah akad untuk pemeliharaan pohon kurma, tanaman (pertanian) dan yang lainnya dengan syarat-syarat tertentu. Musaqah berarti penyerahan pohon kepada orang yang akan mengairi dan merawatnya sampai buahnya benar-benar matang dengan imbalan bagian tertentu dari buah tersebut. ${ }^{4}$ Sedangkan 'maro' merupakan sebuah istilah yang berasal dari Bahasa Jawa 'separo' yang artinya setengah, maksudnya adalah setengah hasil milik petani penggarap dan setengah hasilnya lagi untuk petani pemilik kebun.

Dari interpretasi gramatikal sebagaimana dijelaskan di atas, musaqah dan 'maro' memiliki perbedaan arti namun memiliki maksud yang sama, yaitu merujuk pada sebuah kerjasama di mana kedua belah pihak membagikan hasil sesuai kesepakatan. Musaqah merupakan nama sebuah akad dalam Fikih Islam untuk sebuah kerjasama di mana pemilik kebun memberikan kebunnya kepada tukang kebun agar dipelihara dan penghasilan yang didapat dari kebun itu dibagi antara keduanya sesuai kesepakatan. Untuk membedakannya dari akad serupa yaitu muzara'ah dan mukhabarah, ciri khusus akad musaqah adalah pohon yang dijadikan objek akad sudah tersedia di atas lahan/ kebun. Hal inilah yang juga serupa dengan konsep 'maro' atas kebun kopi yang dilakukan antarpetani kopi di Desa Gunung Sari. Dengan demikian, maka secara gramatikal dapat di katakan bahwa konsep musaqah dalam Fikih relevan dengan konsep ‘maro’ antarpetani kopi di Desa Gunung Sari.

Apabila ditinjau dari segi teleologis, yaitu maksud diadakannya sebuah hukum, terutama tujuan sosial masyarakatnya, musaqah memiliki maksud dan tujuan untuk saling tolong menolong antarmanusia, di mana orang yang tidak memiliki tenaga untuk mengerjakan/

${ }^{3}$ Firman Muh. Arif, "Muzara'ah dan Pengembangan Ekonomi Umat di Pedesaan”, Jurnal al-Amwal, Vol. 3, No. 2, September 2018. Hlm. 113-119.

${ }^{4}$ Ely Herawati, "Tinjauan Hukum Islam terhadap Musaqah antara Pemilik Kebun Karet dan Penyadap di Desa Tanjung Bulan Kecamatan Rambang Kuang Kabupaten Ogan Ilir”, Skripsi, UIN Raden Fatah Palembang, 2017. Hlm. 42. 
mengelola kebun akan terbantu dengan orang lain yang akan menggarap dan mengelola kebunnya, ia akan tetap mendapatkan hasil dari kebunnya tanpa harus membayar secara langsung orang tersebut, tetapi dengan kesepakatan pembagian hasil panen. Hal serupa juga menjadi tujuan utama dari adanya kerjasama 'maro' antarpetani kopi di Desa Gunung Sari. Dari tujuan ini maka kedua belah pihak yaitu petani pemilik kebun dan petani penggarap memiliki hubungan simbiosis mutualisme, yakni sama-sama menguntungkan.

Dengan demikian, apabila dilihat dari perspektif kedua interpretasi gramatikal dan teleologis, maka dapat disimpulkan bahwa kerjasama maro antarpetani kopi yang dilaksanakan di Desa Gunung Sari relevan dengan konsep musaqah yang dikenal dalam Fikih Islam.

\section{KESIMPULAN}

Kerjasama 'maro' antarpetani kopi di Desa Gunung Sari, Kecamatan Ulu Belu, Kabupaten Tanggamus pada umumnya dilakukan antara petani pemilik kebun kopi dan petani penggarap dengan ketentuan presentase pembagian hasil sebesar 50\%:50\%. Pengerjaan dan pengelolaan kebun kopi secara keseluruhan menjadi kewajiban petani penggarap, yaiu berupa pemupukan kebun kopi, penyemprotan rumput dan serangga, merapihkan batang pohon (ngeranting), memetik buah kopi, menjemur kopi, menggiling kopi, bahkan ada yang sampai menjual kopi.

Dalam Islam, bentuk kerjasama di mana sudah terdapat pohon di atas sebuah lahan (kebun) disebut dengan kerjasama musaqah. Dasar hukum musaqah adalah sebuah Hadis yang diriwayatkan oleh Muslim dari Ibnu Umar yang artinya adalah "sesungguhnya Rasulullah SAW telah memberikan kebun beliau kepada penduduk Khaibar agar dipelihara oleh mereka dengan perjanjian mereka akan memperoleh setengah dari penghasilannya, baik dari buahbuahan maupun tanamannya." Hikmah dari adanya akad musaqah diantaranya adalah menghilangkan kemiskinan dan memberikan kesempatan berupa saling tukar manfaat diantara manusia. Dengan demikian, maka akan menimbulkan rasa saling peduli antarmanusia yang berujung oada mashlahah untuk keduanya.

Apabila ditinjau dari interpretasi gramatikal dan interpretasi teleologis, maka kerjasama 'maro' yang dilakukan antar para petani kopi di Desa Gunung Sari telah relevan dan sesuai dengan konsep musaqah yang dikenal dalam Fikih. Oleh sebab itu, dapat dikatakan bahwa kerjasama 'maro' antarpetani kopi yang dilakukan di Desa Gunung Sari tersebut merupakan salah satu bentuk implementasi konsep kerjasama musaqah pada masa sekarang.

\section{DAFTAR PUSTAKA}

Anggriawan dan Toti Indrawato, (2013), "Peranan Komoditi Gambir Terhadap Perekonomian Kabupaten Lima Puluh Kota Provinsi Sumatera Barat", JURNAL EKONOMI, Vol. 21, No. 2, Juni

Arif, Firman Muh., (2018), "Muzara'ah dan Pengembangan Ekonomi Umat di Pedesaan", Jurnal al-Amwal, Vol. 3, No. 2, September.

Aziz, M. Ali Abdul, (2019), "Pelaksanaan Akad Musaqah dalam Pengelolaan Lahan Pohon Kelapa dalam Meningkatkan Ekonomi Masyarakat (Studi pada Lembaga Masyarakat Desa Hutan Wana Tani Manunggal Karangbendo Kecamatan Ponggok Kabupaten Blitar), skripsi, IAIN Tulung Agung. 
Seminar Nasional Penelitian dan Pengabdian kepada Masyarakat

Universitas Sang Bumi Ruwa Jurai Tahun 2020

Famulia, Ledy., (2016), “Konsep Al-Iqtha' dalam Islam dan Relevansinya dengan Redistribusi Tanah di Indonesia (Studi Putusan MK No. 87/PUU-XI/2013)”, Jurnal Iijtihad, Vol. 10, No. 2.

Fatwa DSN-MUI No. 15/DSN-MUI/2000 Tentang Prinsio Distribusi Hasil Usaha dalam Lembaga Keuangan Syariah.

Ghazaly, Abdurrahman, dkk., (2010), Fikih Muamalat, Jakarta: Kencana.

Harun, 2017, Fiqh Muamalah, Surakarta: Muhammadiyah University Press.

Hamidi, Jazim, (2005), Hermeneutika Hukum, Yogyakarta: UII Press.

Herawati, Ely. (2017), “Tinjauan Hukum Islam terhadap Musaqah antara Pemilik Kebun Karet dan Penyadap di Desa Tanjung Bulan Kecamatan Rambang Kuang Kabupaten Ogan Ilir", Skripsi, UIN Raden Fatah Palembang.

https://almanhaj.or.id/1642-musaqah-ihyaa-ul-mawaat.html diakses pada 19 September 2020.

https://kbbi.kemdikbud.go.id/entri/relevansi diakses pada 9 September 2020.

https://kbbi.web.id/tani diakses pada 20 September 2020.

Imram, Arsyali, dkk, (2017), “Tinjauan Hukum Islam Berkenaan Akad Musaqah terhadap Praktek Bagi Hasil Pertanian Studi Kasus DesanKarangheleut Kecamatan Situraja Kabupaten Sumedang”, Prosiding Keuangan dan Perbankan Syariah, Vol. 3, No. 1.

Monografi Pekon Gunung Sari Keadaan pada Bulan Maret Tahun 2020.

Sari, Almaidah, (2013),"Implementasi Musaqah dalam Usaha Agribisis antara Pemilik Kebun dan Petani ditinjau dari Ekonomi Islam (Studi Kasus Perkebunan Semangka Kecamatan Tampan)", Skripsi, UIN SUSKA Riau.

Wahyuningsih, Tri, (2011), "Sistem Bagi Hasil Maro sebagai Upaya Mewujudkan Solidaritas Masyarakat”, Jurnal Komunitas, Vol. 3, No. 2. 